\title{
Biodiversity impacts of climate change - the PRONAS software as educational tool
}

\author{
K. Ulbrich, O. Schweiger, S. Klotz, and J. Settele \\ Helmholtz Centre for Environmental Research-UFZ, Theodor-Lieser-Straße 4, 06120 Halle, Germany \\ Correspondence to: K. Ulbrich (karin.ulbrich@ufz.de)
}

Received: 4 May 2015 - Revised: 12 October 2015 - Accepted: 3 November 2015 - Published: 26 November 2015

\begin{abstract}
Loss of biodiversity under climate change is on the top of European research agendas. However, there is a huge gap between the scientific and the educational communities: Only a small amount of current knowledge reaches the young generation. We faced the challenge of how to transfer results of biodiversity research to the reality of school classrooms - in a way that raises interest, awareness and motivation among students from the age of 12 to 19. We developed the educational software PRONAS (PROjections of NAture for Schools) to show how scientists handle questions about the impact of climate change on the habitats of many European species. About 50 European plant and animal species have been used to demonstrate habitat losses, habitat shifts, and mismatch of habitat dynamics of interacting species. The software was developed with a bottom-up approach, and a manual for applying the software in the classroom was written in close cooperation with teachers. We included specific elements of didactic approaches such as storylines describing future scenarios, projections and simulations of species' future climatic niches, as well as the combination of virtual and real excursions. PRONAS is freely accessible in German and English on www.ufz.de/pronas-lernsoftware. Feedback was given by about 100 teachers from German and other European schools at six teacher workshops and by 141 students from four German schools. While most teachers confirmed that the designed format of knowledge transfer is attractive and contributes to knowledge building and awareness raising, many students older than 16 felt under-challenged. Altogether, we found that "educational software" is a useful format for scientific outreach which is worth joint efforts of scientists and educators and which needs more support and incentives for scientists to go forward in this direction.
\end{abstract}

\section{Introduction}

Climate change and dramatic loss of biodiversity are essential subjects for research. In a world that is changing at faster rates and over larger scales than ever recorded before, there is an urgent need for knowledge to understand and manage the biosphere. This knowledge concerns unprecedented stressors for biological diversity such as habitat fragmentation, introduction of alien species, overfishing of oceans, and the rapid growth of the world population, which are particular threats to biodiversity in the short term to midterm (Lubchenco, 1998; Barnosky et al., 2011). But looking 50 years into the future and beyond, the effects of climate are likely to become increasingly prominent relative to the other factors (Thuiller, 2007; Settele et al., 2014).
It is now widely recognized that further climate change seems to be inevitable - even if global emissions reductions and mitigation efforts over the next decades prove to be successful. Therefore, adaptation was added to the policy agenda, and EU member states started to develop national adaptation strategies (Biesbroek et al., 2010).

A large number of research projects have been funded by the EU and by national governmental bodies, and extensive knowledge about climate change impact has been accumulated in the scientific community (Henle et al., 2010; Kühn et al., 2008; Potts et al., 2011; Settele et al., 2007, 2010, 2014). All of them conclude that we will lose a major portion of biological diversity in the first half of this century if we do not act immediately.

Comprehensive information is needed before people become active. That is why outreach is an important part of 
most biodiversity research projects. This is in accordance with the statement of the 1992 Rio Summit that scientists have the responsibility to inform the public about their research and to contribute to raising the awareness for biodiversity preservation (United Nations, 1992). Knowledge transfer is particularly needed in the education sector. Traditional roles of science are not limited to discovering, communicating, and applying knowledge; they also include training the next generation of scientists (Lubchenco, 1998; Hulme, 2014).

Scientists have proposed numerous approaches to bridging the "knowing-doing gap", have developed alternative formats for science communication outside of formal research publications, and have improved partnership and participatory approaches between scientists and practitioners (Lawton, 2007; DeFries, 2012; Hulme et al., 2011; and Hulme, 2014). Examples of such formats are atlases (Settele et al., 2008, 2010; Rasmont et al., 2015), decision support tools (Mewes et al., 2015; Ulbrich et al., 2008), databases (AmphibiaWeb, 2015; Kühn et al., 2004), and web-based tools and games (Fürst et al., 2010; Schulze et al., 2014).

In the present paper, we address stakeholders who are often underestimated or at least underrepresented: school students, who are the young citizens and consumers of today and the decision makers of tomorrow. Students need to gain core competencies that enable them to develop responsible decision making in the future and to ensure the development of the next generation of scientists (Hopkinson and James, 2010; Ledley et al., 2011).

Young people's engagement with global issues in general is quite low in the EU-27. The Eurobarometer survey on "Youth on the Move" (European Commission, 2012) found that only $3.2 \%$ of young Europeans participated in NGOs active in the domain of climate change, while $5.2 \%$ were engaged with human rights or global development issues. When it comes to human rights or global development, participation of young people ranges from $11.1 \%$ in Denmark to $1.3 \%$ in Hungary (3.2\% in Germany). In terms of climate change, young people's participation ranges from $5.6 \%$ in Ireland to $1.3 \%$ in Poland (2.3\% in Germany). Young people's participation in both domains tends to be higher in Western Europe than in Eastern Europe. Albert et al. (2010) found that an increasing number of young people in Germany are becoming aware of problems caused by climate change. Fiftythree percent of 12- to 15-year-old students perceive climate change as a real threat, and they are ready to change personal behaviour, while $26 \%$ think that the problem of climate change is being overestimated. However, $21 \%$ say that climate change poses a big problem but that humans cannot solve it.

Scientists, in particular biodiversity researchers, face the challenge of bringing across their research to the daily lives of school students in a way that favours the sustainable engagement of young people for biodiversity preservation. To meet students' needs and interests, scientists have to adapt their comprehensive knowledge base in a proper way and to transform it according to the specificity of the target groups. In particular, the level of understanding complex processes has to be considered. An analysis of curricula in the subjects of biology and geography, performed for all of 16 German federal states, showed that complexity and abstraction of topics increases with students' age (Lindau, 2011). Whereas biology lessons in the 5th grade (11-12 years) are based on species (e.g. mammals, birds, or flowering plants), students of the 11th grade (17-18 years) learn about ecosystems and biodiversity protection. Geography lessons deal with basic agriculture aspects in the 5th grade and with climate change scenarios and landscape ecology in the 11th and 12th grades. Experience from previous projects shows that teachers need (1) simple and short-term solutions, whereas ecologists tend to provide complex and long-term results; (2) easy access to research results apart from journal articles and specific data bases; and (3) support in understanding of scientific methods addressing uncertainties in environmental issues.

The objective of our present paper was to show how scientists can deal with these challenges for effective outreach. We developed an educational software called PRONAS (PROjections of NAture for Schools) to pass research results from the sphere of science "down to earth" - to the classrooms. Our tool is based on the contents of the EU-funded research project ALARM (Assessing LARge scale Risks for biodiversity with tested Methods) with a special emphasis on future scenarios and projections of climate niches for European plants and animals (Settele et al., 2005, 2010; www.alarmproject.net). We describe the development process, the structure and the main features of PRONAS. Finally, we discuss aspects of our outreach experience.

\section{Development of PRONAS}

\subsection{Scientific content and didactic approach}

The ALARM project has integrated the research results of more than 250 scientists of 68 institutions from 35 countries. Research focused on the assessment and forecast of changes particularly in biodiversity but also in structure, function, and dynamics of ecosystems. In particular, risks arising not only from climate change but also from environmental chemicals, biological invasions, and pollinator loss in the context of current and future European land use patterns have been assessed. Socio-economic scenarios have been applied to simulate future environmental threats and to quantify risks subsequent on these (Rounsevell et al., 2006; Settele et al., 2007; Spangenberg et al., 2012; Plieninger et al., 2013). Scenarios are alternative, dynamic stories that capture key ingredients of our uncertainty about future ecological, social, economic, and political trends. The storylines of the three basic scenarios in ALARM do not represent predictions but rather possible development paths: SEDG (sustainable European development goal) aims at integrated ecological, social, insti- 
tutional, and economic sustainability; BAMBU (business as might be usual) includes measures for mitigation or adaptation to climate change, but not for explicit protection of biodiversity; and GRAS (growth applied strategy) is a scenario of unlimited economic growth considering adaptation to climate change but no measures for its reduction (Settele et al., 2007; Spangenberg et al., 2012). Studies applying those scenarios indicate that completely different species such as plants (Thuiller et al., 2005), reptiles and amphibians (Araújo et al., 2006), birds (Virkkala et al., 2008), butterflies (Settele et al., 2008), or bumblebees (Rasmont et al., 2015) - will suffer significantly from climate change, as climatic conditions in their habitats become hostile and they cannot reach new appropriate areas in a conceivable time. Moreover, those effects may be amplified by disturbed biotic interactions (Schweiger et al., 2008, 2012).

To adapt the huge knowledge base of the ALARM project, we decided to consider the following aspects:

a. provide scientific content and methods applied by scientists dealing with uncertainties and addressing main drivers of global biodiversity loss;

b. link to the everyday life of students by applying scenarios to plant and animal species living in students' backyards;

c. motivate one to have a live experience of nature, combining the virtual with the real world, counteracting the negative messages of biodiversity loss, motivating students to individual activities, and providing links to citizen science projects;

d. develop a "bottom-up" style and design in close collaboration with school students - searching for the right software style between "drill-like programs" and highly animated computer game (see Schneider and Wittenbröker, 2010);

e. link educational software with curricula and favour the implementation in classroom teaching by involving educators from the very beginning of the project.

\subsection{The network}

Effective scientific outreach is much more than just oneway transfer of knowledge. Instead, continuous, constructive feedback is needed to face the challenges. In the two communities of scientists and educators there are still many different approaches in understanding, communicating, and applying scientific subjects. Furthermore, for most scientists it is difficult to translate their terminology into a language understandable for students and teachers. On the other hand, teachers often lack the time necessary to prepare scientific information for classroom teaching (Ledley et al., 2011). The software PRONAS has been developed in close collaboration between ecologists, teachers, environmental educators, and

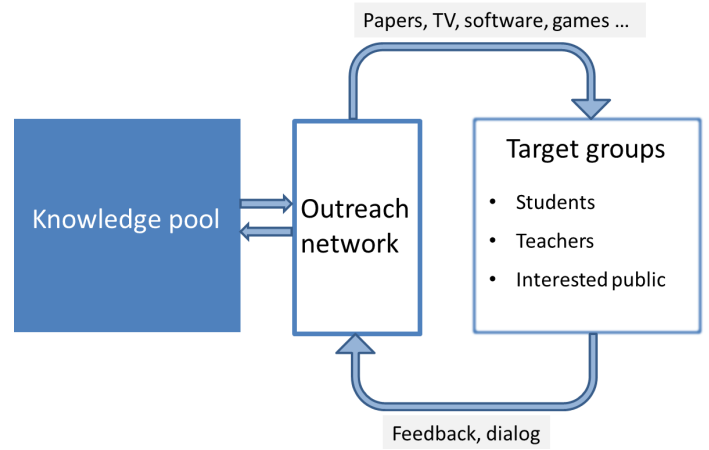

Figure 1. The "Knowledge pool" represents scientific knowledge and results that have to be transformed by a network to be understandable by the target groups. In a permanent dialog with this network, students and teachers give feedback about their needs. In the PRONAS outreach network, biodiversity researchers collaborate with teachers, environmental educators, and pedagogical scientists.

pedagogical scientists (Fig. 1). The leading team consisted of a researcher (ecologist), a designer, and a software engineer. Software programming was realized using the Adobe Flash editor with ActionScript. Three schools and four environmental visitor centres have been involved in the project. Five teams of two 16-year-old school students performed students' projects related to PRONAS design and content (with a duration of 10 months each). Five seminars for German teachers and one Europe-wide teacher workshop were used to discuss PRONAS with about 100 teachers. Five students studying to become teachers dealt with PRONAS topics in their final theses. Altogether, six workshops were held with all of the team members. This network was one of the most essential preconditions (a) for the tailoring of the complex scientific knowledge base to didactic purposes and (b) for the implementation in classroom lessons and out-of-classroom learning.

\subsection{Software evaluation}

In the course of software development, six evaluation studies were performed (Table 1). Target groups included German school students at the age of 12 to 18 , coming from four schools, as well as educators from several schools and institutions.

\section{Results}

\subsection{Software elements}

\subsubsection{Storylines}

Insightful and compelling narratives are important to successfully communicate with the non-scientific scholars (Vervoort et al., 2014). Scientific visualization should not tell a story just by itself but rather communicate science and sci- 
Table 1. Evaluation studies.

\begin{tabular}{l|l|l}
\hline No. & Topic & Target group \\
\hline 1 & $\begin{array}{l}\text { Biodiversity knowledge, } \\
\text { expectations of PRONAS }\end{array}$ & $\begin{array}{l}88 \text { students (12 to } 18 \text { years } \\
\text { old) }\end{array}$ \\
\hline 2 & Benefits of PRONAS & 15 teachers \\
\hline 3 & Test and critical analysis & 15 students (17 to 18 years) \\
\hline 4 & Test and critical analysis & 22 students (17 to 18 years) \\
\hline 5 & Test and critical analysis & 16 students (16 to 17 years) \\
\hline 6 & Critical analysis & $\begin{array}{l}14 \text { educators involved in } \\
\text { PRONAS development }\end{array}$ \\
\hline
\end{tabular}

entific content. In the "Guided tour" of PRONAS, the comiclike characters Tom and Tina want to learn about biodiversity and how their environment will look in 20 or 50 years. They visit scientists and discuss impacts of climate change for three basic scenarios (see below). Tom and Tina ask whether we can still observe the brimstone butterfly or the common toad in 2050. How long will the spruce forests in the Harz Mountains in Central Germany still exist? PRONAS provides insights into the work of ecology researchers, giving the example of more than 50 European plants and animals (e.g. butterflies, amphibians, trees, and flowering plants).

Figure 2 shows a scientist explaining that completely different species will suffer significantly from climate change, as climatic conditions in their habitats become increasingly hostile and they cannot reach new appropriate areas in conceivable time. This is demonstrated using the example of the butterfly Titania's Fritillary (Boloria titania) and its food plant common bistort (Polygonum bistorta) (Schweiger et al., 2008). This example shows that niches of interacting species can change in different ways. There is an increasing spatial mismatch over time regarding the niches of plants and butterflies. Consequently, the area suitable for the butterflies may decrease significantly. A major objective of our project was to enable and to foster the understanding of school students of scientific methods for risk assessment in the field of biodiversity. The main focus was placed upon the methods of future scenarios of global change combined with modelling of climatic niches. Three scenarios - Green, Yellow, and Red - have been derived in accordance with the three basic scenarios of the ALARM project.

Students apply the scenarios in two interactive tools: the "scenario test" and the "butterfly tool". In the interactive scenario test the user is asked how Europe will look in the year 2050. For several socio-economic fields - from policy to land use and consumption - he selects his answers out of three given options.

\subsubsection{Projections and simulations}

With climatic niche models, the impact of climate change on biodiversity can be described mathematically and projected into the future (Pompe et al., 2011). Figure 4 shows the projection of the future potential distributions of the European peacock (Nymphalis io) according to the assumed future conditions under the different scenarios of global change. The butterfly simulation tool includes projections for 15 European butterfly species. Their potential geographical distributions can be simulated with time steps of 1 year until the year 2100. Occupied, lost and newly gained areas are shown in these projections under the assumptions of the scenarios Green, Yellow, or Red (Fig. 3).

\subsubsection{Virtual excursions and citizen science projects}

The software provides virtual excursions in different landscapes that are designed in a way which favours "retracing" of virtual trips in reality, or - at least - those excursions may motivate the participants to go out for individual trips. By undertaking virtual excursions, students "experience" landscapes (e.g. dry and wet grasslands). Species that are subject to research studies and climatic modelling are "discovered" and "monitored" on the virtual trips. With projections (see Fig. 3) the user is transferred to the year 2050 or 2080, where he or she gets informed about possible area gains or losses of the species for each of the scenarios. Virtual excursions seem to be a useful method to combine abstract learning with live experience of nature, as they provide frames for discussing the impact of climate change on species and their habitats.

The animated species gallery includes portraits of more than 30 plant and animal species. Geographical distributions observed in the year 2000 are displayed and compared with the potential geographical distributions in 2080 (assuming the scenario Red, which equals GRAS in ALARM). Species well known to children such as the blue tit (Parus caeruleus), the European hare (Lepus europaeus), and the stinging nettle (Urtica dioica) represent species living "in the backyard".

From the perspective of educational psychology, engagement with educational software should aim at gaining competencies for problem solving and at being relevant for everyday life (Lude, 2006). Furthermore, educators emphasize the importance of pairing risk communication with potential risk-reducing actions that might be performed by the students. That is why links to citizen science projects are provided that inspire and promote activities in observation, monitoring and nature protection, e.g. monitoring of butterflies in Germany (www.tagfalter-monitoring.de; Kühn et al., 2010); the Germany-wide monitoring of the great burnet (Sanguisorba officinalis), a wet meadow plant (www.ufz.de/ wiesenknopf; Ulbrich et al., 2014); or the EU-wide tree monitoring (www.beagleproject.org). 


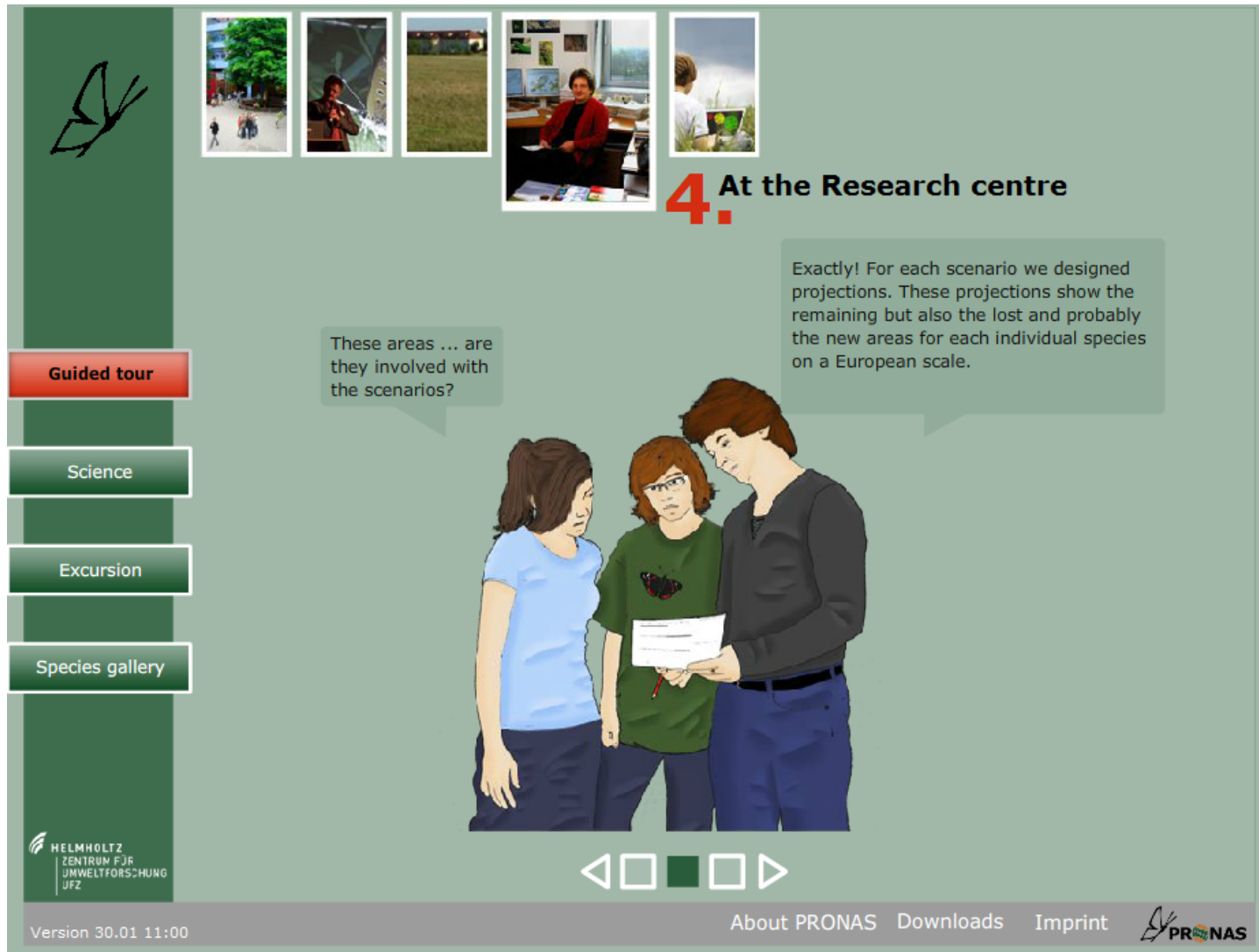

Figure 2. Guided tour of PRONAS: Tom and Tina meet a scientist.

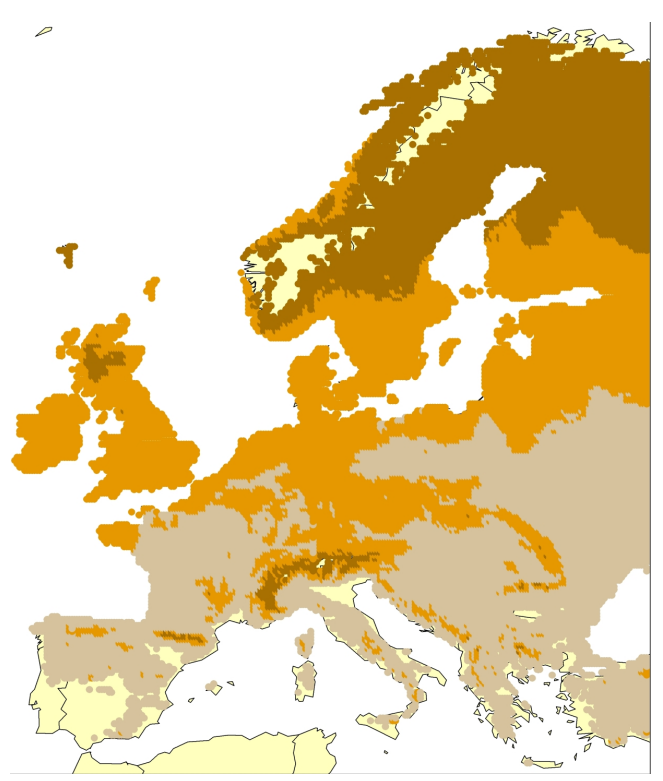

Figure 3. Example for the projections used in PRONAS: projected areas for the European peacock (Nymphalis io) assuming scenario Red for the year 2080 (Settele et al., 2008).

\subsection{Implementation in school education}

Discussions with teachers helped us to develop a manual that shows in detail how the software can be implemented in German school education (Ulbrich et al., 2011). The manual includes more than 30 teaching units for the subjects of biology, geography, mathematics and computer science, and for multidisciplinary teaching. They can be used in the classroom, in out-of-classroom learning or on "project days". Most units are designated for time periods of 45 or $90 \mathrm{~min}$. They describe how computer work can be combined with traditional teaching methods such as worksheets, division into small groups of up to four students, oral discussions, and short presentations. PRONAS includes 20 interactive tests for students where they can check their knowledge or get inspirations for new discussion. The educational software can be freely accessed via the Internet or downloaded for offline use. It is eligible for flexible use in classroom teaching and for individual use by students as well. Additionally to the German version an English version is provided, which allows the software to be used beyond Germany. 
(a) 1

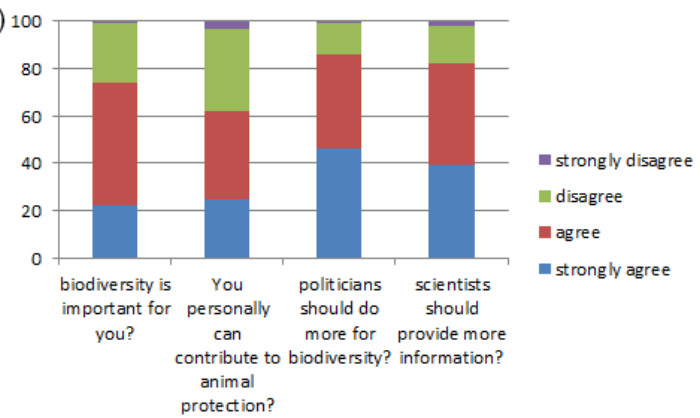

(c)

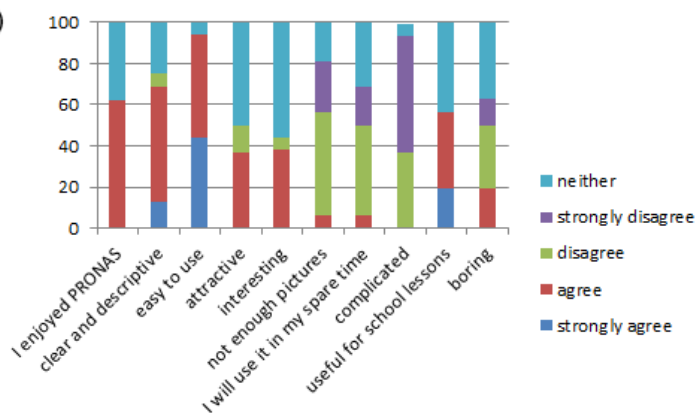

(b) 100

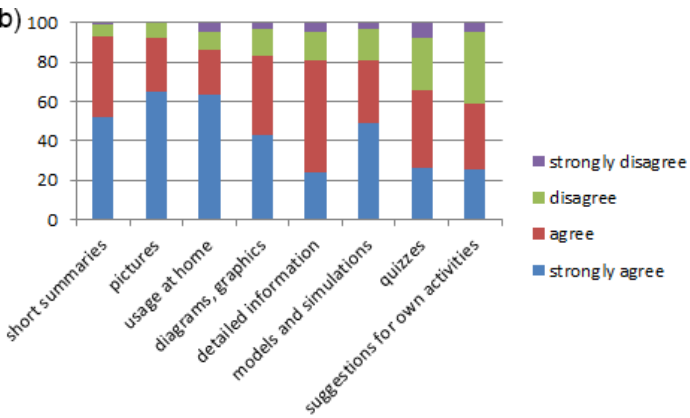

(d)

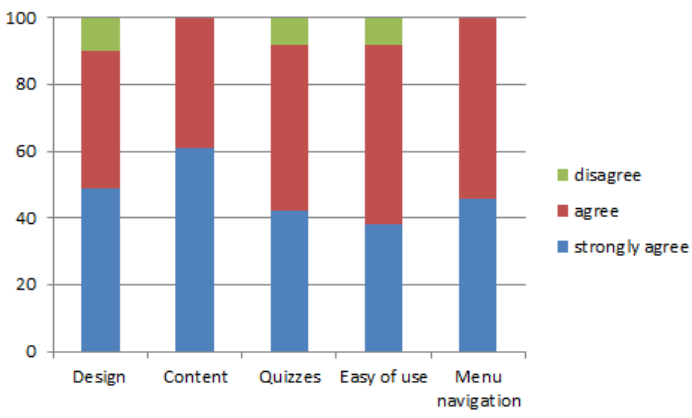

Figure 4. Results of evaluation studies with different target groups of German students and teachers: (a, b) preliminary study in the starting period with 88 students (12 to 18 years) of a school in Halle. They had to answer the questions (a) "do you think that ... ?" and (b) "which general software elements are important for you?"; (c) 16 students (16 to 17 years) of a school in Leipzig evaluated the beta version of PRONAS; (d) 14 educators who were involved in the development evaluated the final version of PRONAS.

\subsection{Evaluation results}

Six evaluation studies have been performed (Tables 1 and 2, and Figs. 4a-d). The first study was realized in 2009 in the starting period of the project. Eighty-eight students from a gymnasium in Halle (Germany), aged 12 to 18 years, answered questions on biodiversity and software (Fig. 4a). Results show the high expectations placed upon politicians and scientists: $86 \%$ of students confirmed that politicians should do more for biodiversity, and $82 \%$ said that scientists should provide more information about risks for biodiversity. Three of four students confirmed that biodiversity is important for them, and $62 \%$ thought that they could personally contribute to animal protection. Asked for desired software traits, two of three students strongly agreed with richly illustrated tools that they could use at home. Only one of four students strongly agreed with the provision of suggestions for own activities and detailed information (Fig. 4b). Fifteen 17to 18-year-old students of a gymnasium in Düsseldorf (Germany) worked with PRONAS for $2 \mathrm{~h}$ (evaluation study 3 ). Seven percent of them strongly agreed with the statement that the software stimulates students' interest for the environment, $79 \%$ agreed, and $14 \%$ disagreed.

In another $2 \mathrm{~h}$ study the software was tested by 22 students aged 17 to 18 (evaluation study 4). Sixty-nine percent of them found the software clear and descriptive, and $56 \%$ said that it is useful for school lessons. However, more than $50 \%$ did not find it attractive. Sixty-three percent would not use it in their spare time, and $43 \%$ found it boring. Nearly $30 \%$ of the 17- to 18-year-old students participating in studies 3 and 4 said they feel underestimated as PRONAS seems to be designed for younger students. Sixteen students aged 16 to 17 gave their feedback after they had tested the software for $1 \mathrm{~h}$ (evaluation study 5). Most of them agreed that it was easy to use the software, that it is understandable and that it is clearly structured. However, less than $40 \%$ found it attractive or interesting (Fig. 4c). In the final period of software development 14 educators who were involved in the project gave their feedback (evaluation study 6). The highest score was given to the general content. The lowest agreement was reached in relation to the ease of use (Fig. 4d). Answering the question "what did you like most?", every second teacher highlighted the general concept and design, and one of four favoured the presentation of the scenarios.

A survey performed with 15 teachers indicated the benefits that they see in the software (Table 2). Answers are structured by the main topics highlighted by the teachers. Many of them emphasized the scenario approach, the potential of combining virtual and real learning, and the helpful manual for the implementation in school lessons. However, nearly all participants said that the software would be even more attractive 
Table 2. Feedback of 15 teachers about the benefits of PRONAS.

\begin{tabular}{|c|c|}
\hline Topic & Individual answers of teachers \\
\hline $\begin{array}{l}\text { Awareness of climate change } \\
\text { and sustainability }\end{array}$ & $\begin{array}{l}\text { Direct relation to climate change } \\
\text { Make subject of climate change clear } \\
\text { Awareness for the impact of climate change on species distribution } \\
\text { Stimulates thinking about own lifestyle - change own behaviour } \\
\text { Education for sustainability }\end{array}$ \\
\hline Scenarios & $\begin{array}{l}\text { Vivid demonstrations through links to everyday life (scenarios) } \\
\text { Students deal with scenarios, get insights, awareness } \\
\text { Scenarios raise awareness for processes in the environment } \\
\text { Interesting to see changes until } 2100 \text { when applying scenarios } \\
\text { Multidisciplinary approach } \\
\text { Societal approach }\end{array}$ \\
\hline $\begin{array}{l}\text { Better understanding of } \\
\text { environmental issues }\end{array}$ & $\begin{array}{l}\text { Development of core competencies } \\
\text { PRONAS makes things visible that are not so clear yet } \\
\text { Make topics clear that are not subject to lessons } \\
\text { Insights in environmental research } \\
\text { Environmental topics more detailed than in normal lessons } \\
\text { Demonstrates species diversity } \\
\text { Students deal with scientific methods } \\
\text { Easy to deal with the topic, with concrete data or excursions }\end{array}$ \\
\hline Implementation & $\begin{array}{l}\text { Digital learning is up-to-date } \\
\text { Easy to develop lesson units } \\
\text { Easy to derive students' projects }\end{array}$ \\
\hline Excursions & $\begin{array}{l}\text { Good preparation for real excursions } \\
\text { Virtual excursions - information about new regions } \\
\text { May stimulate students to perform ecological studies in their spare time }\end{array}$ \\
\hline Attractiveness & $\begin{array}{l}\text { Initiates empathy } \\
\text { Sensibilization for the topic } \\
\text { Provides information in an attractive way that affects thinking of stu- } \\
\text { dents }\end{array}$ \\
\hline
\end{tabular}

if examples of excursions in other European countries were included.

\section{Discussion}

Science is expected not only to generate and to publish knowledge but also to make it applicable for society (United Nations, 1992). To fulfill this task, scientists have to transfer their findings to formats useful and usable by politicians and other target groups. Moreover, specific transfer channels have to be established to reach the individual target groups, and specific products for those groups have to be designed. The presented educational software, PRONAS, combined with a teacher manual may serve as an example for such a tailored outreach product. It addresses school students from 12 to 19 and their teachers, and it has been developed in close collaboration with them. In this way, we went beyond the common one-way knowledge transfer from science to school. Continuous and constructive feedback given by both educators and students enabled meeting their needs and expectations.

PRONAS is a module for academic and extracurricular education and fits in the environmental framework that is designated by the UN Decade for Education for Sustainable Development from 2005 to 2014 and the UN Decade for Biodiversity from 2011 to 2020 (Lude, 2010; Ulbrich et al., 2010). The increasing flexibility of the educational system in Germany in terms of the acceptance of external resources (UNESCO, 2011) had a favourable effect on the project. Rigid German curricula have been replaced by educational standards that determine which competencies students should develop (OECD, 2005). Three competencies are in the focus: linked, anticipatory, and critical thinking. In the learningteaching arrangement, PRONAS establishes relationships to the living environment of students that are based on scientific findings. This creates a solid basis for the three future scenarios. Applying alternative scenarios makes future developments directly accessible to students. They get an im- 
pression about the complexity and interactivity of different factors which determine our future.

The feedback of teachers shows that, first of all, PRONAS offers an opportunity to better understand how the effects of human activities like climate change and land use impact biodiversity at regional and global levels. It increases the awareness of young people about their own role and responsibility. By providing innovative learning approaches, PRONAS may inspire a variety of students - those who are already interested in biodiversity issues and even those who may not respond well to environmental topics but like to work with the computer. Secondly, the combination of virtual and real excursions and nature studies encourages students to pursue their own nature conservation activities. Thirdly, teachers highlight the benefit of the manual that allows them to effectively implement the software in school lessons. They confirm that the pedagogical principles of PRONAS are orientation for vision, action, and reflection as well as linked learning (Lude, 2010).

Evaluation studies among 16- to 18-year-old students indicate that further software projects have to consider a stricter age-oriented approach as students from 12 to 19 may represent more than one target group. Students prefer short texts, rich illustrations, and highly interactive game-like tools and tests. Further evaluation studies should be performed among younger students to figure out the specificity of this group.

Altogether, we found that creating educational software is an appropriate way to create outreach channels for results of biodiversity research. It combines academic content with game-like interactive elements and receives positive responses from both students and teachers. More and more teachers engage in applying scientific outreach. However, successful development of such projects requires the consolidation and enhancement of existing outreach networks and channels (public media, workshops, school labs etc.). Therefore, permanent resources and efforts are needed even after the initial project has been finished. Experience shows, however, that resources provided for educational purposes are often limited in research centres and incentives for scientists to engage in this field are still too scarce. As there is an urgent need to bring knowledge that is available in biodiversity science from the spheres of science into classrooms, scientists and educators should further develop outreach networks transferring scientific knowledge bases to adaptive formats.

\section{Summary}

The educational software PRONAS was created to bridge the gap between biodiversity research and school education. An effective format for scientific outreach was developed in close collaboration with educators.
Author contributions. K. Ulbrich developed the concept of the educational software. Together with J. Settele she headed the project. J. Settele was the scientific coordinator of the ALARM project. O. Schweiger developed niche model approaches and performed modelling studies. S. Klotz coordinated the main scientific studies that were used as the basis of PRONAS. K. Ulbrich prepared the manuscript with contributions from all co-authors.

Acknowledgements. We thank the Deutsche Bundesstiftung Umwelt (DBU) for the financial support. J. Nöller inspired us to Fig. 1. We are very grateful to two anonymous reviewers who gave helpful comments.

Edited by: K. Jax

Reviewed by: two anonymous referees

\section{References}

Albert, M., Hurrelmann, K., and Quenzel, G.: 16.ShellJugendstudie 2010, TNS Infratest, Frankfurt a.M., Fischer, 29 pp., 2010.

AmphibiaWeb: Information on amphibian biology and conservation [web application], Berkeley, California, AmphibiaWeb, available at: http://amphibiaweb.org/, last access: 28 September 2015.

Araújo, M. B., Sykes, M. T., and Prentice, I. C.: Climate change threats to plant diversity in Europe, Proceedings of the National Academy of Sciences of the United States of America, 102, 8245-8250, 2005.

Araújo, M. B., Thuiller, W., and Pearson, R. G.: Climate warming and the decline of amphibians and reptiles in Europe, J. Biogeogr., 33, 1712-1728, 2006.

Barnosky, A. D., Matzke, N., Tomiya, S., Wogan, G. O. U., Swartz, B., Quental, T. B., Marshall, C., McGuire, J. L., Lindsey, E. L., Maguire, K. C., Mersey, B., and Ferrer, E. A.: Has the Earth's sixth mass extinction already arrived?, Nature, 471, 51-57, 2011.

Biesbroek, G. R., Swart, R. J., Carter, T. R., Cowan, C., Henrichs, T., Mela, H., Morecroft, M. D., and Rey, D.: Europe adapts to climate change: Comparing National Adaptation Strategies, Global Environmental Change, 20, 440-450, 2010.

DeFries, R. S., Ellis, E. C., Chapin, F. S., Matson, P. A., Turner, B. L., Agrawal, A., Crutzen, P. J., Field, C., Gleick, P., Kareiva, P. M., Lambin, E., Liverman, D., Ostrom, E., Sanchez, P. A., and Syvitski, J.: Planetary Opportunities: A Social Contract for Global Change Science to Contribute to a Sustainable Future, BioScience, 62, 603-606, 2012.

European Commission: EU Youth Report 2012, Luxembourg: Publications Office of the European Union, 284 pp., available at: http://ec.europa.eu/youth/ (last access: 23 November 2015), 2012.

Fürst, C., Volk, M., Pietzsch, K., and Makeschin, F.: Pimp your landscape! A tool for qualitative evaluation of the effects of regional planning measures on ecosystem services, Environ. Manage., 46, 953-968. 2010.

Henle, K., Kunin, W., Schweiger, O., Schmeller, D. S., Grobelnik, V., Matsinos, Y., Pantis, J., Penev, L., Potts, S. G., Ring, I., Similä, J., Tzanopoulos, J., van den Hove, S., Baguette, M., Clobert, J., Excoffier, L., Lengyel, S., Marty, P., Moilanen, A., Porcher, 
E., Storch, D., Steffan-Dewenter, I., Sykes, M. T., Zobel, M., and Settele, J.: Securing the Conservation of biodiversity across Administrative Levels and spatial, temporal, and Ecological Scales - research needs and approach of the SCALES project, GaiaEcological Perspectives for Science and Society, 19, 187-194, 2010.

Hopkinson, P. and James, P.: Practical pedagogy for embedding ESD in science, technology, engineering and mathematics curricula, International Journal of Sustainability in Higher Education, 11, 365-379, 2010.

Hulme, M., Mahony, M., Beck, S., Görg, C., Hansjürgens, B., Hauck, J., Nesshöver, C., Paulsch, A., Vandewalle, M., Wittmer, H., Boschen, S., Bridgewater, P., Diaw, M.C., Fabre, P., Figueroa, M., Heong, K.L., Korn, H., Leemans, R., Lovbrand, E., Norowi, H.M., Monfreda, C., Pielke, Jr. R., Settele, J., Winter, M., Vadrot, A.B.M., Van den Hove, S., and Van der Sluijs, J.: Science-Policy Interface: Beyond Assessments, Science, 333, 697-698, 2011.

Hulme, P. E.: Bridging the knowing-doing gap: know-who, knowwhat, know-why, know-how and know-when, J. Appl. Ecol., 51, 1131-1136, 2014.

Kühn, E., Harpke, A., Hirneisen, N., Feldmann, R., Leopold, P., and Settele, J.: Establishing a Volunteer-based Butterfly Monitoring Scheme - the German Experience, in: Atlas of Biodiversity Risk, edited by: Settele, J., Penev, L., Georgiev, T., Grabaum, R., Grobelnik, V., Hammen, V., Klotz, S., Kotarac, M., and Kühn, I., Pensoft, Sofia, Moscow, 242-243, 2010.

Kühn, I., Durka, W., and Klotz, S.: BiolFlor - a new plant-trait database as a tool for plant invasion ecology, Divers. Distrib., 10, 363-365, 2004.

Kühn, I., Sykes, M. T., Berry, P. M., Thuiller, W., Piper, J. M., Nigmann, U., Araújo, M. B., Balletto, E., Bonelli, S., Cabeza, M., Guisan, A., Hickler, T., Klotz, S., Metzger, M., Midgley, G., Musche, M., Olofsson, J., Paterson, J. S., Penev, L., Rickebusch, S., Rounsevell, M. D. A. R., Schweiger, O., Wilson, E., and Settele, J.: MACIS: Minimisation of and adaptation to climate change impacts on biodiversity, Gaia-Ecological Perspectives For Science and Society, 17, 393-395, 2008.

Lawton, J. H.: Ecology, politics and policy, J. Appl. Ecol., 44, 465474, 2007.

Ledley, T. S., Dahlman, L., McAuliffe, C., Haddad, N., Taber, M. R., Domenico, B., Lynds, S., and Grogan, M.: Making Earth Science Data Accessible and Usable in Education, Science, 333, 18381839, 2011.

Lindau, A.-K.: PRONAS im Unterricht - die Methode der realen und virtuellen Exkursion, in: Lebensräume von Tieren und Pflanzen simulieren - Zukunftsszenarien zum Einfluss des Klimawandels,, edited by: Ulbrich, K., Lindau, A. K., Hörning, C., and Settele, J., Pensoft Publishers, Sofia, 34-37, 2011.

Lubchenco, J.: Entering the Century of the Environment: A New Social Contract for Science, Science, 279, 491-497, 1998.

Lude, A.: Natur erfahren und für die Umwelt handeln - zur Wirkung von Umweltbildung, NNA-Berichte 19/2, 18-33, 2006.

Lude, A.: The spirit of teaching ESD - Biodiversity in educational projects, in: Biodiversity in Education for Sustainable Development - Reflection on School - Research Cooperation, edited by: Ulbrich, K., Settele, J., Hörning, C., and Benedict, F. F., Pensoft Publishers, Sofia, 10-17, 2010.

Mewes, M., Drechsler, M., Johst, K., Sturm, A., and Wätzold, F.: A systematic approach for assessing spatially and temporally dif- ferentiated opportunity costs of biodiversity conservation measures in grassland, Agr. Syst., 137, 76-88, 2015.

OECD - Organisation for Economic Co-operation and Development: Definition und Auswahl von Schlüsselkompetenzen - Zusammenfassung, available at: http://www.oecd.org/pisa/ 35070367.pdf (last access: 23 November 2015), 2005.

Plieninger, T., Bieling, C., Ohnesorge, B., Schaich, H., Schleyer, C., and Wolff, F.: Exploring Futures of Ecosystem Services in Cultural landscapes through Participatory Scenario Development in the Swabian Alb, Germany, Ecology and society, 18, 39, doi:10.5751/ES-05802-180339, 2013.

Pompe, S., Berger, S., Bergmann, J., Badeck, F., Lübbert, J., Klotz, S., Rehse, A. K., Söhlke, G., Sattler, S., Walther, G. R., and Kühn, I.: Modellierung der Auswirkungen des Klimawandels auf die Flora und Vegetation in Deutschland, BfN-Skripten, 304, 1-98, 2011.

Potts, S. G., Biesmeijer, J. C., Bommarco, R., Felicioli, A., Fischer, M., Jokinen, P., Kleijn, D., Klein, A. M., Kunin, W. E., Neumann, P., Penev, L. D., Petanidou, T., Rasmont, P., Roberts, S. P. M., Smith, H. G., Sorensen, P. B., Steffan-Dewenter, I., Vaissiere, B. E., Vila, M., Vujic, A., Woyciechowski, M., Zobel, M., Settele, J., and Schweiger, O.: Developing European conservation and mitigation tools for pollination services: approaches of the STEP (Status and Trends of European Pollinators) project, J. Apicult. Res., 50, 152-164, 2011.

Rasmont, P., Franzén, M., Lecocq, T., Harpke, A., Roberts, S., Biesmeijer, K., Castro, L., Cederberg, B., Dvorak, L., Fitzpatrick, Ú., Gonseth, Y., Haubruge, E., Mahé, G., Manino, A., Michez, D., Neumayer, J., Ødegaard, F., Paukkunen, J., Pawlikowski, T., Potts, S., Reemer, M., Settele, J., Straka, J., and Schweiger, O.: Climatic Risk and Distribution Atlas of European Bumblebees, BioRisk, 10, 1-236, 2015.

Rounsevell, M. D. A., Reginster, I., Araújo, M. B., Carter, T. R., Dendoncker, N., Ewert, F., House, J. I., Kankaanpää, S., Leemans, R., Metzger, M. J., Schmit, C., Smith, P., and Tuck, G.: A coherent set of future land use change scenarios for Europe, Agriculture, Ecosystems \& Environment, 114, 57-68, 2006.

Schneider, O. and Wittenbröker, V.: Digitale Lernwelten und Lernsoftware: Die > Designer-Perspektive $<$ oder Wie kann man Metaphern mit Leben füllen?, in: Digitale Lernwelten Konzepte, Beispiele und Perspektiven, edited by: Hugger, K. U. and Walber, M., VS Verlag für Sozialwissenschaften, 269-284, 2010.

Schulze, J., Martin, R., Finger, A., Lindner, M., Pietzsch, K., Werntze, A., and Seppelt, R.: Design, implementation and test of a serious online game for exploring complex relationships of sustainable land management and human well-being, Environmental Modelling \& Software, 65, 58-66, 2014.

Schweiger, O., Settele, J., Kudrna, O., Klotz, S., and Kühn, I.: Climate change can cause spatial mismatch of trophically interacting species, Ecology, 89, 3472-3479, 2008.

Schweiger, O., Heikkinen, R. K., Harpke, A., Hickler, T., Klotz, S., Kudrna, O., Kühn, I., Pöyry, J., and Settele, J.: Increasing range mismatching of interacting species under global change is related to their ecological characteristics, Global Ecol. Biogeogr., 21, 88-99, 2012.

Settele, J., Hammen, V., Hulme, P., Karlson, U., Klotz, S., Kotarac, M., Kunin, W., Marion, G., O’Connor, M., Petanidou, T., Peterson, K., Potts, S., Pritchard, H., Pysek, P., Rounsevell, M., 
Spangenberg, J., Steffan-Dewenter, I., Sykes, M., Vighi, M., Zobel, M., and Kuhn, I.: ALARM - Assessing LArge-scale environmental Risks for biodiversity with tested Methods, GaiaEcological Perspectives for Science and Society, 14/1, 69-72, 2005.

Settele, J., Kühn, I., Klotz, S., Hammen, V., and Spangenberg, J.: Is the EC afraid of its own visions?, Science, 315, 1220, doi:10.1126/science.315.5816.1220b, 2007.

Settele, J., Kudrna, O., Harpke, A., Kuhn, I., Van Swaay, C., Verovnik, R., Warren, M., Wiemers, M., Hanspach, J., Hickler, T., Kuhn, E., Van Halder, I., Veling, K., Vliegenthart, A., Wynhoff, I., and Schweiger, O.: Climatic Risk Atlas of European Butterflies, BioRisk, 1, 1-710, 2008.

Settele, J., Penev, L., Georgiev, T., Grabaum, R., Grobelnik, V., Hammen, V., Klotz, S., Kotarac, M., and Kuhn, I. (Eds.): Atlas of Biodiversity Risk, Pensoft Publishers, Sofia, Moscow, 280 pp., 2010.

Settele, J., Scholes, R., Betts, R., Bunn, S., Leadley, P., Nepstad, D., Overpeck, J. T., and Taboada, M. A.: Terrestrial and Inland Water Systems, in: Climate Change 2014: Impacts, Adaptation, and Vulnerability. Part A: Global and Sectoral Aspects, Contribution of Working Group II to the Fifth Assessment Report of the Intergovernmental Panel on Climate Change, edited by: Field, C. B., Barros, V. R., Dokken, D. J., Mach, K. J., Mastrandrea, M. D., Bilir, T. E., Chatterjee, M., Ebi, K. L., Estrada, Y. O., Genova, R. C., Girma, B., Kissel, E. S., Levy, A. N., MacCracken, S., Mastrandrea, P. R., and White, L. L. (Eds.): Cambridge University Press, Cambridge, United Kingdom and New York, NY, USA, 271-359, 2014.

Spangenberg, J. H., Carter, T. R., Fronzek, S., Jaeger, J. A. G., Jylhä, K., Kühn, I., Omann, I., Paul, A., Reginster, I., Rounsevell, M., Stocker, A., Sykes, M. T., and Settele, J.: Scenarios for investigating risks to biodiversity, Global Ecol. Biogeogr., 21, 5-18, 2012.

Thuiller, W. S. L.: Climate change and the ecologist, Nature, 448, 550-552, 2007.

Ulbrich, K., Drechsler, M., Wätzold, F., Johst, K., and Settele, J.: A software tool for designing cost-effective compensation payments for conservation measures, Environmental Modelling and Software, 23, 122-123, 2008.
Ulbrich, K., Settele, J., Hörning, C., and Benedict, F. F.: Biodiversity in Education for Sustainable Development - Reflection on School - Research Cooperation, Pensoft Publishers, 150 pp., 2010.

Ulbrich, K., Lindau, A. K., Hörning, C., and Settele, J.: Lebensräume von Tieren und Pflanzen simulieren - Zukunftsszenarien zum Einfluss des Klimawandels, Pensoft Publishers, Sofia, 195 pp., 2011.

Ulbrich, K., Körnig, S., Lodemann, T., Eschenhagen, W., Bindel, L., and Settele, J.: Klima und biologische Vielfalt - Erforscht mit der Lernsoftware PRONAS. MNU, Verlag Klaus Seeberger, Neuss, 66, 165-172, 2013.

Ulbrich, K., Kühn, E., Wiemers, M., Harpke, A., and Settele, J.: "Find the Great Burnet" - a Citizen Science project, Oedippus, 29, 21-31, 2014.

UNESCO: Working group on biological diversity: Biological Diversity and education for Sustainable Development - Key Topics and Starting Points for Educational Programmes, Deutsche UNESCO-Kommission (Ed.), Bonn, Deutsche UNESCOKommission e.V. (DUK - German Commission for UNESCO), available at: http://www.bne-portal.de (last access: 14 April 2014), 2011.

United Nations: Multilateral Convention on biological diversity (with annexes), Concluded at Rio de Janeiro on 5 June 1992, in: United Nations Treaty Series, Vol. 1760, 146 (Article 2. Use of Terms), 1992.

Vervoort, J. M., Keuskamp, D. H., Kok, K., van Lammeren, R., Stolk, T., Veldkamp, T. A., Rekveld, J., Schelfhout, R., Teklenburg, B., Borges, A. C., Jánoškóva, S., Wits, W., Assmann, N., Dezfouli, E. A., Cunningham, K., Nordeman, B., and Rowlands, H.: A sense of change: media designers and artists communicating about complexity in social-ecological systems, Ecol. Soc., 19, 10, doi:10.5751/ES-06613-190310, 2014.

Virkkala, R., Heikkinen, R. K., Leikola, N., and Luoto, M.: Projected large-scale range reductions of northern-boreal land bird species due to climate change, Biol. Conserv., 141, 1343-1353, 2008. 